ISSN 1412-2936

EISSN 2549-7308

\title{
PENGARUH VARIABEL MEDIASI RASA PERCAYA PADA NILAI TERHADAP NIAT PEMBELIAN ULANG PRODUK UMKM DI KABUPATEN CIREBON
}

\author{
Tri Budi Prasetyo \\ tri.budi@umc.ac.id
}

Arif Nurudin

arifnurudin@gmail.com

\section{Universitas Muhammadiyah Cirebon}

\begin{abstract}
Abstrak. Green marketing bertujuan ke arah untuk berkomunikasi bahwa merek atau perusahaan adalah peduli lingkungan hidup. Penelitian ini bertujuan untuk mengukur sejauh mana konsep green marketing yang dilakukan pada UMKM yang berada di kawasan Kabupaten Cirebon. Niat beli dapat dipengaruhi oleh beberapa faktor, salah satunya adalah nilai yang dirasakan oleh konsumen. Pada penelitian ini memasukan rasa percaya sebagai variabel mediasi guna meningkatkan niat beli ulang, berdasarkan uji $t$ diperoleh nilai $t$ dengan siginifikansi secara berturut-turut senilai sebesar 11,660 dan 0,000 , sehingga varibel nilai dinyatakan berpengaruh positif dan siginifikan terhadap variabel niat beli ulang, dengan menggunakan Metode Sobel test perhitungan nilai $Z_{\text {hitung }}$ diperoleh nilai 6,156 lebih besar dari $Z_{\text {tabel }}$ dengan tingkat signifikansi 0,05 , yaitu 1,96, sehingga dapat disimpulkan bahwa rasa percaya memediasi hubungan kausal antara nilai terhadap niat beli ulang.
\end{abstract}

Keyword : Green Marketing, UMKM, Pembelian Ulang, Nilai, Rasa Percaya.

\section{PENDAHULUAN}

$\begin{array}{crr}\text { Green } & \text { Marketing adalah } \\ \text { pemasaran } & \text { suatu produk yang }\end{array}$

diasumsikan sebagai produk yang ramah lingkungan. Oleh karena itu Green Marketing terdiri dari berbagai macam aktifitas termasuk modifikasi produk, perubahan dalam proses, pergantian packaging, bahkan perubahan pada promosi. Green Bertujuan ke arah untuk berkomunikasi bahwa merek atau perusahaan adalah peduli lingkungan hidup.

Konsep green marketing beberapa tahun belakang menjadi konsep yang paling sering dibicarakan dan menjadi fokus utama dari perusahaan-perusahaan dunia. Hal ini dikarenakan perusahaan telah menyadari perlunya proteksi lingkungan dan kesinambungan yang berwawasan lingkungan. Oleh sebab itu kedua hal tersebut telah menjadi bagian acuan bagi perusahaan.

Tidak terkecuali bagi jenis usaha mikro, kecil menengah atau yang dikenal dengan istilah Usaha Mikro, Kecil Menengah (UMKM). Adanya tuntutan konsumen secara global mengharuskan UMKM untuk memiliki orientasi green marketing. Dalam hal ini, produk ataupun jasa yang dihasilkan harus memiliki konsistensi yang tinggi terhadap nilai-nilai lingkungan yang meliputi seluruh aspek yang ada dalam usahanya misalnya dalam pengembangan produk, produksi, pengelolaan energi dan limbah, proteksi 
konsumen, kebijakan lingkungan dan sosial.

Penelitian ini bertujuan untuk mengukur sejauh mana konsep green marketing yang dilakukan pada UMKM yang berada di kawasan Kabupaten Cirebon. Kawasan perkotaan dengan latar belakang masyarakat yang memiliki dinamika sangat tinggi dan memiliki informasi yang sangat berkembang menuntut adanya produk-produk yang ramah llingkungan. Walaupun di sisi lain ada sebagian masyarakat yang belum menyadari arti pentingnya produk-produk ramah lingkungan, pihak produsen diharapkan untuk bisa mengedukasi konsumen tidak terkecuali bagi UMKM. Disisi lain, green marketing merupakan suatu strategi yang dapat membantu UMKM mendapatkan pelanggan dan keuntungan.

\section{Pertanyaan Penelitian}

1. Mengetahui pengaruh nilai terhadap pembelian ulang

2. Mengetahui pengaruh rasa percaya sebagai variabel mediasi pada nilai terhadap pembelian ulang

\section{Landasan Teori}

\section{Green Marketing}

Konsep Green Marketing merupakan suatu istilah yang telah lama muncul dalam dunia bisnis yang muncul tahun 1980 akhir. John Grant dalam bukunya "The Green Marketing Manifesto" membagi tujuan Green Marketing ke dalam 3 tahap/bagian, yaitu green, greener dan greenest. Sedangkan manfaat green marketing adalah untuk menghasilkan produk yang lebih ramah lingkungan, bagi produsen sebagai upaya untuk memenuhi keinginan masyarakat akan produk yang ramah lingkungan dan untuk inovasi.

Pride \& Farrel dalam Jain dan Kaur (2004) menyatakan bahwa "Green Marketing adalah upaya orang mendesain, mempromosikan dan mendistribusikan produk yang tidak merusak lingkungan dan aman untuk dikonsumsi". Sedangkan Polansky (dalam Jain dan Kaur, 2000) menyatakan bahwa green marketing adalah "Semua aktivitas yang dirancang untuk menghasilkan dan memfasilitasi setiap pertukaran yang dapat memuaskan kebutuhan dan keinginan manusia dengan dampak kerusakan lingkungan yang minimal".

Produk yang ramah lingkungan dikenal dengan istilah Green Product /commodity. Menurut Andrea Prothero dan James A Fitcheet (Journal of macro marketing, 2000): Green commodity refers to goods that are designed, produced and exchanged while causing minimal detriment to environment. Heizer dan Render, 2006:224 menyatakan bahwa tujuan dari green marketing adalah : mengembangkan produk yang lebih aman dan ramah lingkungan, meminimalkan limbah bahan baku dan energi, membedakan produk dari persaingan, mengurangi kewajiban akan masalah 
lingkungan hidup dan meningkatkan efektivitas biaya dengan memenuhi peraturan lingkungan hidup agar dikenal sebagai perusahaan yang baik.

UMKM

\section{Berdasarkan Undang-Undang} Nomor 20 Tahun 2008, pengertian Usaha Mikro Kecil dan Menengah (UMKM) adalah:

1. Usaha mikro adalah usaha produktif milik orang perorangan dan/atau badan usaha perorangan yang memenuhi kriteria usaha mikro sebagaimana diatur dalam undangundang ini.

2. Usaha kecil adalah usaha ekonomi produktif yang berdiri sendiri, yang dilakukan oleh orang perorangan atau badan usaha yang bukan merupakan anak perusahaan atau bukan cabang perusahaan yang dimiliki, dikuasai, atau menjadi bagian baik langsung maupun tidak langsung dari usaha menengah atau usaha besar yang memenuhi kriteria usaha kecil sebagaimana dimaksud dalam undang-undang ini.

3. Yang dimaksud usaha kecil dan menengah adalah kegiatan usaha dengan skala aktivitas yang tidak terlalu besar, manajaemen masih sangat sederhana, modal yang tersedia terbatas, pasar yang dijangkau juga belum luas.
4. Usaha menengah adalah usaha ekonomi produktif yang berdiri sendiri, yang dilakukan oleh orang perseorangan atau badan usaha yang bukan merupakan anak perusahaan atau cabang perusahaan yang dimiliki, dikuasai, atau menjadi bagian baik langsung maupun tidak langsung dengan usaha kecil atau usaha besar dengan jumlah kekayaan bersih atau hasil penjualan tahunan sebagaimana diatur dalam undang-undang ini. Dunia usaha adalah usaha mikro, usaha kecil, usaha menengah, dan usaha besar yang melakukan kegiatan ekonomi di Kudus dan berdomisili di Kudus.

5. Kata lain dari pelaku usaha adalah wirausahawan (entrepreneuship). Secara sederhana, wirausahawan (entrepreneuship) dapat diartikan sebagai pengusaha yang mampu meliat peluang dengan mencari dana serta sumber daya lain yang diperlukan untuk menggarap peluang tersebut, berani menanggung risiko yang berkaitan dengan pelaksanaan bisnis yang ditekuninya, serta menjalankan usaha tersebut dengan rencana pertumbuhan dan ekspansi.

Kriteria Usaha Mikro, Kecil Dan Menengah (UMKM) menurut UU Nomor 20 Tahun 2008 digolongkan berdasarkan jumlah asset dan omset yang dimiliki oleh sebuah usaha.

Tabel 1

Kriteria UMKM 
ISSN 1412-2936

EISSN 2549-7308

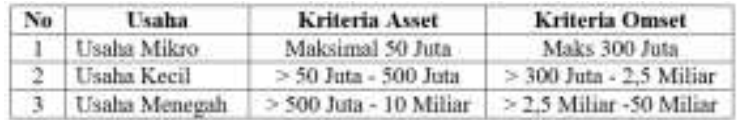

Sumber : Kementrian Koperasi dan Usaha Kecil dan Menengah, 2012

\section{Pembelian Ulang}

Niat beli adalah kecenderungan konsumen untuk bertindak terhadap sebuah objek dan secara umum diukur dari niat beli konsumen (Kim et al., 2008). Niat beli ini dalam kerangka teori Reasoned Action adalah bagian dari perilaku (behavior) sebagai hasil dari sikap konsumen terhadap obyek. Artinya apabila konsumen mempunyai sikap positif terhadap sebuah merek/produk maka ia mempunyai niat untuk membeli produk tersebut.

Berdasarkan uraian diatas peneliti dapat menyimpulkan niat pembelian adalah bagian dari perilaku konsumen dari hasil pengidentifikasian dari semua pilihan yang ada yang sistematis setelah mempertimbangkan keuntungan dan kerugian yang mungkin akan terjadi dengan didukung oleh informasi-informasi yang diperoleh sehingga konsumen cenderung untuk membeli produk tersebut.

Kotler (2008) bahwa perilaku konsumen menentukan niat beli konsumen. Proses pembelian konsumen merupakan pendekatan penyesuaian masalah yang terdiri sari 5 tahap yang dilalui konsumen. Kelima tahap tersebut adalah pengenalan kebutuhan, pencarian informasi, evaluasi berbagai alternatif, keputusan pembelian, dan perilaku pasca pembelian. Kelima tahap tersebut tidak selalu terjadi, khususnya dalam pembelian yang tidak memerlukan keterlibatan yang tinggi dalam pembelian.

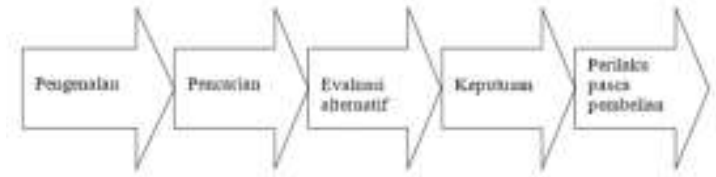

Sumber: Kotler and Amstrong (2008)

Gambar 1

Tahapan Pembelian

Berdasarkan uraian diatas penulis dapat menarik kesimpulan yang termasuk dalam tahapan niat pembelian pengenalan kebutuhan, pencarian informasi, dan evaluasi berbagai alternative. Tahapan keputusan pembelian dan perilaku pasca pembelian bukan termasuk dalam niat karena kedua tahapan tersebut sudah termasuk proses pembelian dan dampak yang dirasakan setelah melakukan pembelian.

\section{Rasa Percaya}

Pemasaran relasional merupakan konsep penting dalam pemasaran strategis. Menurut Ganesan (1994) mengartikan bahwa rasa percaya merupakan konsep yang sangat penting dalam hubungan pemasaran. Rasa percaya dianggap sebagai cara yang paling penting dalam jangka panjang.

Rasa percaya disebabkan dari tiga yaitu : rasa percaya integritas, kebajikan, dan kemampuan, rasa percaya adalah suatu harapan yang diselenggarakan oleh salah satu pihak bahwa kata, janji, atau 
ISSN 1412-2936

EISSN 2549-7308

pernyataan pihak lain dapat dapat diandalkan (Rotter, 1991; Schurr dan Ozanne, 1995). Selain itu, rasa percaya adalah sejauh mana keyakinan bahwa pihak lain akan berperilaku seperti yang diharapkan (Hart dan Saunders, 1997). Rasa percaya pelanggan merupakan penentu dasar perilaku konsumen jangka panjang (Lee et al., 2011).

Berdasarkan beberapa pendapat yang ada maka dapat disimpulkan rasa percaya merupakan suatu proses kumulatif yang berkembang dalam setiap pengulangan interaksi yang sukses dan merupakan dasar suatu harapan yang diselenggarakan oleh salah satu pihak, janji, atau pernyataan pihak lain dapat dapat diandalkan kebanarannya.

\section{Nilai}

Parasuraman dan Grewal (1999), mendefinisikan nilai yang diterima (perceived value) sebagai suatu konstruk dinamis yang terdiri dari empat tipe nilai yaitu acquisition value, transaction value, in-use value dan redemption value. Acquisition value dijelaskan sebagai keuntungan yang diterima dari harga secara moneter yang telah diberikan. Tansaction value sebagai kesenangan yang konsumen terima pada waktu transaksi. In-use value adalah kegunaan yang diberikan pada konsumen atas penggunaan produk atau jasa. Sementara redemption value adalah keuntungan residual yang diterima pada waktu produk tidak dipakai lagi. Penggunaan definisi tersebut berhubungan satu sama lain dari empat dimensi yang berbeda selama kehidupan produk atau jasa. Aquisition value dan transaction value terlihat selama pembelian, sementara in-use value dan redemption value terlihat setelah pembelian.

Dimensi dari menerima adalah emotional response, quality dan reputation. Sementara dimensi yang berhubungan dengan memberi adalah harga moneter dan harga non moneter. Kombinasi dari biaya moneter dan non moneter yang diterima sama dengan seluruh pengorbanan yang konsumen berikan yang mana berakibat pada nilai jasa.

Nilai yang dirasakan didefinisikan sebagai evaluasi keseluruhan konsumen dari keuntungan bersih dari produk atau jasa berdasarkan penilaian konsumen (Bolton dan Drew, 1991; Patterson dan Spreng, 1997). Penelitian sebelumnya telah banyak dieksplorasi nilai yang dirasakan karena memiliki efek positif pada kinerja pemasaran (Sweeney et al., 1999). Karena nilai yang dirasakan lebih penting, dan perusahaan dapat meningkatkan konsumen membeli niat melalui nilai produk (Steenkamp dan Geyskens, 2006).

Berdasarkan uraian tersebut maka dapat ditarik kesimpulan nilai adalah hasil evaluasi dari hasil perbandingan yang dirasakan oleh konsumen antara harapan dengan yang diterima konsumen, apabila yang diterima lebih besar dari yang 
ISSN 1412-2936

EISSN 2549-7308

diharapkan maka nilai yang diterima oleh konsumen bernilai positif dan sebaliknya apabila yang diterima lebih kecil dari yang diharapkan oleh konsumen maka akan memperoleh nilai negatif.

Penelitian sebelumnya telah banyak dieksplorasi nilai yang dirasakan karena memiliki efek positif pada kinerja pemasaran (Sweeney et al., 1999). Karena nilai yang dirasakan lebih penting, dan perusahaan dapat meningkatkan niat konsumen untuk membeli melalui nilai produk (Steenkamp dan Geyskens, 2006). Nilai yang dirasakan tidak bisa hanya menjadi penentu penting dalam mempertahankan hubungan pelanggan jangka panjang, tetapi juga memainkan peran penting dalam mempengaruhi pembelian niat (Zeithaml, 1998;. Zhuang et al, 2010).

Dari uraian diatas maka dapat ditarik benang merah nilai dapat mengakibatkan penambahan kegunaan dari barang atau jasa, mengurangi biaya yang dikeluarkan, meningkatkan kinerja pemasaran dan dapat mempertahankan hubungan jangka panjang dengan pelanggan untuk melakukan pembelian maupun pembelian ulang pada produk tersebut

\section{Metode Penelitian}

Tipe penelitian yang digunakan adalah tipe eksplanatif. Periset menghubungkan atau mencari sebab akibat dua atau lebih konsep (variable) yang akan diteliti. Periset membutuhkan definisi konsep, kerangka konseptual dan kerangka teori. Periset perlu melakukan kegiatan berteori untuk menghasilkan dugaan awal (hipotesis) antara variable satu dengan yang lainnya (Kriyantono, 2014:69)

\section{Ruang Lingkup Penelitian}

Penelitian ini di lakukan pada UMKM bidang kuliner yang berada di wilayah Kabupaten Cirebon.

\section{Jenis dan Sumber Data}

Data primer adalah data yang diperoleh dari Lapangan (UMKM, khususnya UMKM dibidang kuliner) yang berada di wilayah Kabupaten Cirebon, sedangkan data sekunder adalah data penunjang yang diperoleh dari dinas terkait (Dinas Koperasi dan UMKM Kabupaten Cirebon).

\section{Metode Pengumpulan Data}

Metode pengumpulan data dilakukan dengan memberikan pertanyaan yang telah disiapkan oleh peneliti. Instrumen penelitian yang digunakan oleh peneliti berupa questioner tertutup. Dimana responden cukup memberi tanda silang, mencentang ataupun melingkari sesuai jawaban yang dianggap sesuai.

\section{Metode Analisis Data \\ Validitas}

Metode yang digunakan untuk mencari validitas instrumen adalah korelasi produk momen antara skor setiap butir 
ISSN 1412-2936

EISSN 2549-7308

pertanyaan dengan skor total. Semua item disusun mengikuti prinsip skala Likert (Likert Summated Ratings), maka sebuah item dianggap valid jika koefisien hubungan item tersebut dengan total keseluruhan item yang kemudian kita notasikan sebagai $R$ haruslah lebih besar atau sama dengan $R$ dalam Tabel $r(R \geq$ r).

\section{Reliabilitas}

Model yang digunakan untuk menguji reliabilitas instrumen dalam penelitian ini adalah model koefisien alfa ( $\alpha$ ) dari cronbach. Apabila nilai hitung alpha lebih besar (>) dari nilai $r$ tabel maka angket dinyatakan reliabel. Begitu juga sebaliknya apabila alpha lebih kecil $(<)$ dari $r$ tabel maka angket dinyatakan tidak reliabel.

\section{Regresi Sederhana}

Teknik analisis data yang digunakan adalah analisis regresi linier sederhana yaitu untuk mengetahui pengaruh dari satu variabel independen terhadap satu variabel dependen. Pada analisis regresi linier sederhana menggunakan Uji t.

\section{Uji Mediasi}

Sobel test merupakan uji untuk mengetahui apakah hubungan yang melalui sebuah variabel mediasi secara signifikan mampu sebagai mediator dalam hubungan tersebut. Sebagai contoh pengaruh variabel independen terhadap variabel dependen melalui variabel mediasi mengunakan uji Sobel test.

\section{Pembahasan}

\section{Validitas}

Tabel 2

Uji Validitas

\begin{tabular}{|c|c|c|c|}
\hline Variabel Nilai \\
\hline Pernyataan & $\begin{array}{c}\mathbf{r} \\
\text { hitung }\end{array}$ & $\begin{array}{c}\mathbf{r} \\
\text { tabel }\end{array}$ & Ket \\
\hline X1.1 & 0,853 & 0,195 & Valid \\
\hline X1.2 & 0,799 & 0,195 & Valid \\
\hline X1.3 & 0,815 & 0,195 & Valid \\
\hline X1.4 & 0,807 & 0,195 & Valid \\
\hline X1.5 & 0,778 & 0,195 & Valid \\
\hline Variabel Rasa Percaya \\
\hline Pernyataan & $\begin{array}{c}\text { r } \\
\text { hitung }\end{array}$ & $\begin{array}{c}\mathbf{r} \\
\text { tabel }\end{array}$ & Ket \\
\hline M1 & 0,834 & 0,195 & Valid \\
\hline M2 & 0,752 & 0,195 & Valid \\
\hline M3 & 0,816 & 0,195 & Valid \\
\hline M4 & 0,797 & 0,195 & Valid \\
\hline M5 & 0,820 & 0,195 & Valid \\
\hline
\end{tabular}

Tabel 2 (lanjutan) Uji Validitas

\begin{tabular}{|c|c|c|c|}
\hline \multicolumn{4}{|l|}{ Variabel Niat Beli } \\
\hline Pernyataan & $\begin{array}{c}\mathbf{r} \\
\text { hitung }\end{array}$ & $\begin{array}{c}\mathbf{r} \\
\text { tabel }\end{array}$ & Ket \\
\hline Y1 & 0,749 & 0,195 & Valid \\
\hline Y2 & 0,857 & 0,195 & Valid \\
\hline Y3 & 0,807 & 0,195 & Valid \\
\hline Y4 & 0,785 & 0,195 & Valid \\
\hline Y5 & 0,911 & 0,195 & Valid \\
\hline
\end{tabular}

Berdasarkan uji $\mathrm{r}$ product moment pada tabel 2 diperoleh nilai pada masingmasing pernyataan yang digunakan dalam penelitian dinyatakan Valid $\left(r_{\text {hitung }}>r_{\text {tabel }}\right)$

\section{Reliabilitas}

Tabel 3

Uji Reliabilitas

\begin{tabular}{|l|c|c|c|}
\hline Variabel & $\begin{array}{c}\text { Cronbach's } \\
\text { Alpha }\end{array}$ & $\begin{array}{c}\text { r } \\
\text { tabel }\end{array}$ & Ket \\
\hline Nilai & 0,869 & 0,195 & Relialibel \\
\hline Rasa & 0,861 & 0,195 & Relialibel \\
\hline
\end{tabular}




\begin{tabular}{|l|l|l|l|}
\hline Percaya & & & \\
\hline Niat Beli & 0,881 & 0,195 & Relialibel \\
\hline
\end{tabular}

Dengan menggunakan rumus Alpha Cronbach pada tabel 3 diperoleh nilai pada masing-masing variabel yang digunakan dapal penelitian ini dinyatakan Relialibel (Cronbach Alpha > dari $r_{\text {tabel }}$ ).

\section{Regresi Linier Sederhana}

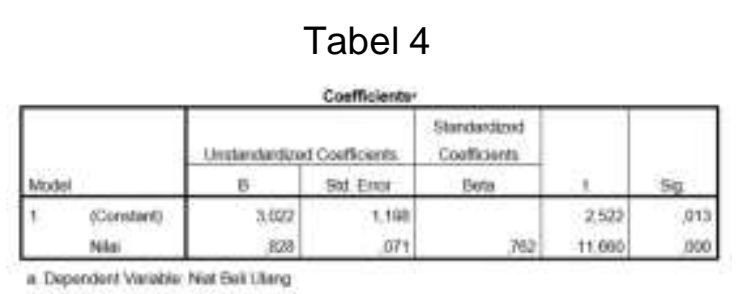

Berdasarkan uji $\mathrm{t}$ pada tabel 4 diperoleh nilai $t$ sebesar 11,660 dengan siginifikansinya 0,000 , sehingga varibel nilai dinyatakan berpengaruh positif dan siginifikan terhadap variabel niat beli ulang. Adapun persamaan regresi linier sederhanya sebagai berikut :

$$
Y=3,022+0,828 X 1+\varepsilon
$$

\section{Uji Mediasi}

\section{Kesimpulan}

Niat beli ulang dapat dipengaruhi oleh beberapa faktor, salah satunya adalah nilai yang dirasakan oleh konsumen. Pada penelitian ini

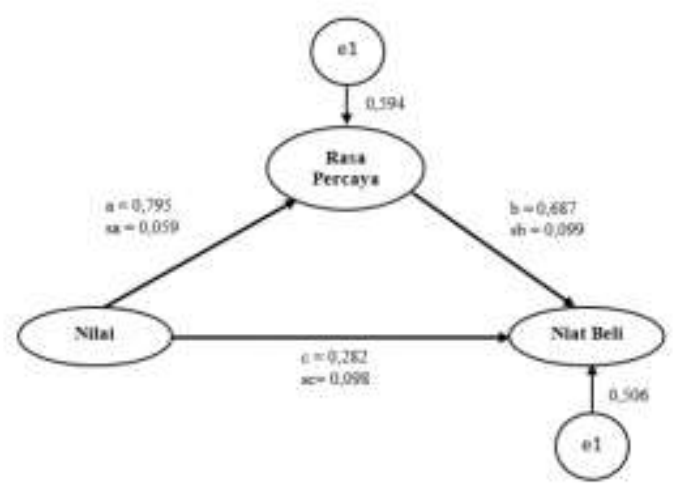

Dengan menggunakan Sobel test perlu kita menghitung standar error ab digunakan rumus berikut :

$S_{a b}=\sqrt{b^{2} s a^{2}+a^{2} s b^{2}+s a^{2} s b^{2}}$

$S_{a b}$

$=\sqrt{0.687^{2} 0,059^{2}+0,795^{2} 0,099^{2}+0,059^{2} 0,099^{2}}$

$S_{a b}=0,089$

Sedangkan untuk nilai $\mathrm{t}$ koefisien ab adalah sebagai berikut:

$Z=\frac{a b}{S_{a b}}=\frac{0,795 \times 0,687}{0,089}=6,156$

Berdasarkan hasil perhitungan nilai $Z$ hitung diperoleh nilai 6,156 lebih besar dari $\mathrm{Z}$ tabel dengan tingkat signifikansi 0,05, yaitu 1,96, sehingga dapat disimpulkan bahwa rasa percaya memediasi hubungan kausal antara nilai terhadap niat beli ulang.

memasukan rasa percaya sebagai variabel mediasi guna meningkatkan niat beli ulang.

Berdasarkan uji $\mathrm{t}$ diperoleh nilai $\mathrm{t}$ dengan siginifikansi secara berturut-turut 
senilai sebesar 11,660 dan 0,000, sehingga varibel nilai dinyatakan berpengaruh positif dan siginifikan terhadap variabel niat beli ulang.

Dengan menggunakan Metode Sobel test perhitungan nilai $Z_{\text {hitung }}$ diperoleh nilai 6,156 lebih besar dari $Z_{\text {tabel }}$ dengan tingkat signifikansi 0,05 , yaitu 1,96, sehingga dapat disimpulkan bahwa rasa percaya memediasi hubungan kausal antara nilai terhadap niat beli ulang.

\section{Daftar Pustaka}

Bolton, R.N. and Drew, JH (1991) "A multistage model of consumers' assessment of service quality and value", Journal of Consumer Research, Vol. 17 No. 4, pp. 375-84.

Ganesan, S. (1994), "Determinants of long-term orientation in buyerseller relationships", Journal of Marketing, Vol. 58 No. 2, pp. 1-19.

Hart, P. and Saunders, C. (1997), "Power and trust: critical factors in the adoption and use of electronic data interchange", Organizational Science, Vol. 8 No. 1, pp. 23-42.

Heizer, J. Dan Render, b. 2006. Operation Management. Edisi Terjemahan. Jakarta: Salemba Empat.

Jain, S.K. and Kaur, G. (2004), "Green marketing: an Indian perspective", Decision, Vol. 31 No. 2, pp. 168209.

Kim, C., Zhao, W. and Yang, K.H. (2008), "An empirical study on the integrated framework of e-CRM in online shopping: evaluating the relationships among perceived value, satisfaction, and trust based on customers' perspectives", Journal of Electronic Commerce in Organizations, Vol. 6 No. 3, pp. 119.
Kotler, Philip. 2008. Manajemen Pemasaran Edisi 12 Jilid 2. Jakarta: Indeks.

Kotler, Philip and Gary Armstrong. 2008. Prinsip-prinsip Pemasaran. Edisi12. Jilid 1. Jakarta: Erlangga.

Lee, J., Park, D-H. and Han, I. (2011),"The different effects of online consumer reviews on consumers' purchase intentions depending on trust in online shopping malls: an advertising perspective", Internet Research, Vol. 21 No. 2, pp. 187-206.

Parasuraman, A., Grewal, Dhruv. (2000). The Impact of Technology on the quality-value-loyalty chain: A research agenda. Journal of the Academy of Marketing Science.

Patterson, P. and Spreng, R. (1997), "Modeling the relationship between perceived value, satisfaction and repurchase intention in a business-tobusiness, service context: an empirical examination", International Journal of Service Industry Management, Vol. 8 No. 5, pp. 414-34.

Prothero, Adrea dan James A Fitchett, 2000, Greening capitalism: Opportunities for a Green Commodity, Journal of Macromarketing, Vol 20 No.1, page 51.

Rotter, J.B. (1991), "Generalized expectancies for interpersonal trust", American Psychologist, Vol. 26 No. 5, pp. 443-50.

Schurr, P.H. and Ozanne, J.L. (1995), "Influences on exchange processes: buyers' preconceptions of a seller's trustworthiness and bargaining toughness", Journal of Consumer Research, Vol. 11 No. 4, pp. 939-53.

Steenkamp, J.B.E.M. and Geyskens, I. (2006), "How country characteristics affect the perceived value of web sites", Journal of 
ISSN 1412-2936

EISSN 2549-7308

Marketing, Vol. 70 No. 3, pp. 13650.

Sweeney, J.C., Soutar, G.N. and Johnson, L.W. (1999), "The role of perceived risk in the qualityvalue relationship: a study in a retail environment", Journal of Retailing, Vol. 75 No. 1, pp. 77105.

Zeithaml, V.A. (1998), "Consumer perceptions of price, quality, and value: a means-end model and synthesis of evidence", Journal of Marketing, Vol. 52 No. 3, pp. 2-22.

Zhuang, W., Cumiskey, K.J., Xiao, Q and Alford, B.L. (2010), "The impact of perceived value on behavior intention: an empirical study", Journal of Global Business Management, Vol. 6 No. 2, pp. 1-7. 